\title{
Pola Asuh Dalam Keluarga Polri di Asrama Polisi Toddopuli Kota Makassar
}

\author{
Hasruddin Nur' ${ }^{1}$, Aditya Abdullah ${ }^{2}$ \\ ${ }^{1}$ Ilmu Pengetahuan Sosial, Universitas Sawerigading Makassar, Indonesia \\ ${ }^{2}$ Ilmu Pengetahuan Sosial, Universitas Negeri Makassar, Indonesia \\ Email asrul23.23.a2@gmail.com
}

\begin{abstract}
Abstrak. Penelitian ini bertujuan untuk (1) Untuk mengetahui pola asuh apa yang digunakan dalam rumah tangga di keluarga Polisi yang bertempat tinggal di Asrama Polisi Toddopuli Kota Makassar, (2) Untuk mengetahui Alokasi waktu dalam keluarga polisi antara pekerjaan, keluarga dan anak, (3) Untuk mengetahui dampak dari penerapan sebuah pola asuh. Jenis penelitian ini merupakan penelitian kuliatatif deskriptif. Teknik untuk mengumpulkan datanya yang digunakan adalah observasi, dokumentasi dan wawancara mendalam terhadap para narasumber dan melibatkan 5 keluarga yang terdiri dari 3 orang yaitu ayah, ibu dan satu orang anak. Syarat sebuah narasumber yaitu kedua orang tuanya berprofesi sebagai seorang polisi, anak yang berusia cukup untuk keterangan, dengan demikian kita menggunkana purposive sampling sebagai metode untuk memilah calon informan. Sedangkan dalam teknik pengabsahan data menggunakan triangulasi sumber. Hasil dari penelitian ini menunjukkan bahwa (1) banyaknya faktor yang mempengaruhi sebuah pola asuh digunakan dalam keluarga menjadi alasan keluarga polisi yang tinggal dalam Asrama Polisi Toddopuli ini menggunakan pola asuh campuran dan pola asuh situasional sebagai pola asuh yang dianggap tepat dalam membesarkan dan memelihara anaknya. (2) Alokasi ini terbagi atas tiga yaitu pekerjaan, keluarga dan anak. Meski demikian fakta yang ditemukan dalam pembagian waktu ini menunjukkan ternyata istri masih memiliki peran yang lebih besar dibanding dengan suami terlepas dari konsep patriarki yang masih banyak digunakan di indonesia. (3) dampak dari penerapan pola asuh ini juga dapat dibagi menjadi dua bagian dimana pola asuh yang berpengaruh terhadap kepribadiana anak dalam keluarga dan lingkungan sosialnya yang tentunya berdampak positive dan negative.
\end{abstract}

Kata Kunci : Pola Asuh, Alokasi Waktu, Dampak

Abstract. This study aims to (1) find out what parenting styles are used in households in the families of the police who live in the Toddopuli Police Dormitory, Makassar City, (2) To determine the time allocation in the police family between work, family and children, (3) To find out the impact of implementing a parenting style. This type of research is a descriptive qualitative research. Techniques to collect data used were observation, documentation and in-depth interviews with informants and involved 5 families consisting of 3 people, namely father, mother and one child. Requirements for a resource are that both parents are police officers, children who are old enough to provide information, thus we use purposive sampling as a method for sorting out potential informants. Meanwhile, the data validation technique uses source triangulation. The results of this study indicate that (1) the number of factors that influence a parenting style used in the family is the reason that the police family living in the Toddopuli Police Dormitory uses mixed and situational parenting styles as parenting styles that are considered appropriate in raising and caring for their children. (2) This allocation is divided into three, namely work, family and children. However, the facts found in this time division show that wives still have a bigger role than husbands despite the patriarchal concept that is still widely used in 
Indonesia. (3) the impact of the adoption of this parenting style can also be divided into two parts where the parenting influences the child's personality in the family and their social environment, which of course has a positive and negative impact.

Keywords: Parenting, Time Allocation, Impact

\section{PENDAHULUAN}

Polisi adalah sebuah profesi pekerjaan yang berada dalam naungan kepemerintahan. Polisi merupakan salah satu profesi yang menerapkan sistem penyetaraan gender di dalamnya. Tidak hanya laki-laki namun perempuan juga dapat mengambil peran dalam menjalankan tugas sebagai seorang polisi. Baik laki-laki maupun perempuan keduanya

diwajibkan untuk menjalankan dan melaksanakan tugas sebagaimana yang telah diatur dalam UU RI No 2 Tahun 2002 tentang Kepolisian Negara Republik Indonesia.

Profersi sebagai soerang polisi biasanya sangat identik dengan laki-laki, namun seiring dengan perkambangan zaman dan peningkatan kebutuhan ini pula yang membuat tidak sedikit perempuan ikut berprofesi sabagai seorang polisi atau dapat kita sebut dengan sebutan Polwan. Dalam hal ini peran tentang gender sangat diperlukan, karena dengan zaman seperti saat ini wanita tidak lagi berada pada wilayah domestic yang selalu berkutat pada peran tradisional. Saat ini wanita juga dapat berada pada wilayah publik yang langsung memberikan mereka kesempatan untuk dapat mengembangkan peran mereka. Peran tradisional yang telah melekat pada wanita membuat mereka hanya menjadi tokoh kedua dalam suatu rumah tangga dan di masyarakat. Hal ini lah yang membuat perempuan berani untuk mengambil peran yang setara dengan laki-laki.

Perempuan juga dituntut untuk berperan aktif. Kehidupan moderen dan era perkembangan yang terjadi pada saat inilah yang membuat para wanita harus dapat menyesuaikan diri dengan keadaan. Sebagai seorang wanita dan sebagai seorang ibu, secara tidak langsung wanita dapat memiliki peran danda dalam keluarga, baik berkarir maupun menjadi ibu rumah tangga seperti pada umumnya. Hal ini dibuktikan dengan adanya perempuan yang memiliki perkejaan atau berprofesi sebagai seorang polisi. Partisipasi perempuan mennyangkut peran tradisi dan transisi. Peran tradisi atau domestik mencakup peran perempuan sebagai istri, ibu, dan pengelola rumah tangga. Sementara peran transisi meliputi pengertian perempuan sebagai tenaga kerja, anggota masyarakat, dan manusia pembangun. Pada peran transisi wanita sebagai tenaga kerja turut aktif dalam kegiatan ekonomis (mencari nafkah) di berbagai kegiatan sesuai dengan keterampilan dan pendidikan yang dimiliki serta lapangan pekerjaan yang tersedia. (Sukesi, 1991 :65)

Hal ini sangat berkenaan bagai mana paham gender berperan penting didalamnya. Menurut Goode (katsum, 2006:45) peran gender adalah kesulitan-kesulitan yang dirasakan dalam menjalankan kewajiban atau tuntutan peran yang berbeda secara bersamaan. Dimana, wanita dituntut untuk dapat menyelesaikan tugas-tugasnya baik didalam keluarga, dikantor, sementara diposisi lain juga dituntut untuk dapat memberikan pekerjaan dengan maksinal. Hal ini lah yang mempengaruhi motivasi wanita untuk dapt menyelesaikan tugas-tugasnya baik dalam kantor maupun dalam keluarga.

Keluarga secara umum dalam masyarakat merupakan satuan terkecil yang tersiri dari beberapa orang, dimana dalam kelarga dipimpin oleh kepala keluarga yang dikenal dengan sebutan ayah atau bapak. Secara

tradisional keluarga dipahami sebagai sekelompok orang yang berhubungan satu sama lain melalui hubungan ikatan darah, perkawinan, adopsi, dan tinggal bersama membentuk unit ekonomi dan melahirkan serta membeserkan anak. Dan keluarga secara kontemporer dipahami sebagai hubungan dimana individu tingal bersama individu yang lain dengan komitmen, membentuk unit ekonomi, mengasuh dan membesarkan serta merawat anak, memiliki identitas yang melekat pada kelompok. Delam sebuah keluarga inti hanya terdiri dari beberapa orang yaitu ayah, ibu serta anak-anak.

Dalam kehidupan berkeluarga ayah, ibu serta anak-anak memiliki tempat tinggal yang sama dan hidup resama sebagai kelompok dalam masyarakat. Dalam proses masyarakat mengalami perubahan-perubahan seiring 
Hasruddin, Aditya. Pola Asuh Dalam Keluarga Polri di Asrama Polisi...

dengan tuntutan kebutuhan dalam rumahtangga kebijakan dalam pemerintah dan lain sebagainya. Melihat perubahan ini peran orang tua dalam menjaga dan membesarkan anak menjadi sangat penting terutama dalam proses tumbuh kembang anak, hal ini dapat dikatakan pula dengan pola asuh.

Pola asuh merupakan metode untuk membesarkan, merawat dan memelihara anak yang diterapkan orang tua kapada anak. Dengan pola asuh yang tepat yang diberikan orang tua kepada anak mampu memberikan efek yang baik pula bagi proses pertumbuhan anak. Secara umum jenis-jenis pola asuh yang kerap diterapkan dalam keluarga ada beberapa macam. Namun penerapan pola asuh ini diterapkan dalam keluarga bergantung bagaimana kondisi keluarga tersebut, mulai dari kondisi ekonomi, sosial, pekerjaan dan lain sebagainya.

Penulis beranggapan bahwasanya salahsatu kondisi yang mampu mempengaruhi pola asuh yang diterapkandalam keluarga yaitu dimana kedua orang tua dari anak tersebut memiliki perkejaan sehinggah waktu yang diluangkan untuk anak sangat minim. Profesi pekerjaan yang digeluti orang tua juga terkadang mampu mempengaruhi pola asuh yang diterapkan dalam membesarkan anak karena tuntutan pekerjaan yang terkadang memaksa orang tua untuk bersikap keras yang secara tidak langsung dapat terbawa dalam keluarga sehinggah salah satu bentuk pola asuh otoriter dapat teraplikasikan.

Gender erat kaitannya dengan pratik pola asuh pada keluarga POLRI. Seperti halnya konsep yang bertemu dengan konteks, maka penelitian ini mengindikasikan gender dan polah asuh sebagai sebuah konsep. Gender dan pola asuh ini, bertemu dalam konteksnya di keluarga POLRI. Konsep dan konteks ini, nantinya akan mewujud sebagai pola asuh yang bisa dipertukarkan. Seorang bapak, mampu menjalankan tugas ibu dalam mengasuh anak, begitu juga sebaliknya. Tidak sedikit dari masyarakat berangapan bahwasanya pola asuh otoriter merupakan pola asuh yang banyak diterapkan dalam keluarga polisi, sehinggah angapan-angapan ini lah yang membuat penulis ingin melakukan pengamatan lebih dalam.

Tujuan penelitian dari penelitian ini adalah: (1) Mengetahui penerapan pola asuh dalam keluarga POLRI Di Kota Makassar; (2) Mengetahui alokasi watu pengasuhan anak dalam keluarga POLISI di Kota Makassar; (3)
Mengetahui dampak terhadap anak dari pola asuh yang ditepkan dalam keluarga POLRI di Kota Makassar.

\section{TINJAUAN PUSTAKA}

\section{A. Gender}

Saat ini peran wanita tidak lagi dapat dipandang sebelah mata, dengan adanya kestaraan gender, wanita memiliki peluang yang besar untuk ikut serta dalam memajukukan negara dan mampu mengambil peran penting dalam keluarga. Dengan ibu rumah tangga yang memiliki perkerjaan sama dengan pekerjaan yang digeluti kali-laki pada umumnya menandakan bahwa gerakan kesetaraan gender ini jalan sebagai mana mestinya.

Istilah Gender tidak luput dari yang Namanya Teori Feminimisme, Feminisme berasal dari kata latin yaitu Femina yang berarti memiliki sifat keperempuanan. Feminisme diawali oleh persepsi tentang ketimpangan posisi perempuan dibandingkan laki-laki di masyarakat. Akibat persepsi ini, timbul berbagai upaya untuk mengkaji penyebab ketimpangan tersebut untuk mengeliminasi dan menemukan formula penyetaraan hak perempuan dan lakilaki dalam segala bidang sesuai dengan potensi mereka sebagai manusia. Operasionalisasi upaya pembebasan diri kaum perempuan dari berbagai ketimpangan perlakuan dalam segala aspek kehidupan disebut gerakan feminis (Riant Nugroho, 2008). Dengan kata lain Gender adalah perbedaan jenis kelamin berdasarkan budaya, di mana laki-laki dan perempuan dibedakan sesuai dengan perannya masing-masing yang dikonstruksikan oleh kultur setempat yang berkaitan dengan peran, sifat, kedudukan, dan posisi dalam masyarakat tersebut. Seks atau jenis kelamin merupakan perbedaan antara laki-laki dengan perempuan berdasarkan ciri biologisnya. Gender adalah perbedaan lakilaki dan perempuan namun dalam konteks sosio-kultural (Riant Nugroho, 2008).

\section{B. Pola Asuh}

Menurut Thoha pola asuh orang tua adalah suatu cara terbaik yang dapat ditempuh orang tua dalam mendidik anak sebagai perwujudan dari rasa tanggung jawab kepada anak.4 Peran keluarga menjadi penting untuk mendidik anak baik dalam sudut tinjauan agama, tinjauan sosial kemasyarakatan maupun tinjauan individu (Thoha, 2004:91). Ahmadi dan Supriono mengatakan orang tua dalam 
mendidik dan mengasuh anak hanis memiliki keaktifan dalam memberikan kasih sayang, bimbingan dan memperhatikan pendidikan anaknya. Adapun makna, bentuk dan pengaruh dan kasih sayang, bimbingan dan perhatian. (Ahmadi, 2008) Bicara mengenai pola asuh, orang tua mempunyai peran dan fungsi yang begitu sentral dalam mendidik anak-anak mereka terutama ketika berada dilingkungan keluarga. Pola asuh merupakan model pemberian perlakuan oleh seseorang terhadap orang lain dalam suatu lingkungan sosial, atau dengan kata lain pola asuh juga dapat dimaknai sebagai perlakuan orang tua terhadap anakanaknya dilingkungan keluarga sehari-hari, baik secara psikis maupun fisik ( Singgih D, 2004) Definisi lain meregkan bahwa interaksi anak dan orang tua mendidik, membinmbing dan mendisiplinkan serta melindungi anak untuk mecapai kedewasaan sesui dengan norma- norma yang ada dalam masyarakat. Pada dasarnya pola asuh dapat diartikan seluruh cara perlakuan orang tua yang diterapkan pada anak. Pola asuh memiliki pengertian pendidikan, sedangkan adalah bimbingan secara sadar oleh pendidik dalam hal ini adalah orang tua terhadap perkenmbangan jasmani dan rohani anak didik menuju tebantuknya kepribadian yang utama ( Danny, 1991). Menurut Baumrind (Dariyo, 2004) membagi pola asuh orang tua menjadi 4 macam, yaitu: (1) Pola Asuh Otoriter (parent oriented) Ciri pola asuh ini menekankan segala aturan orang tua harus ditaati oleh anak. Orang tua bertindak semena-mena, tanpa dapat dikontrol oleh anak. Anak harus menurut dan tidak boleh membantah terhadap apa yang diperintahkan oleh orang tua; (2) Pola Asuh Permisif Sifat pola asuh ini, children centered yakni segala aturan dan ketetapan keluarga di tangan anak. Apa yang dilakukan oleh anak diperbolehkan orang tua, orang tua menuruti segala kemauan anak ;(3) Pola Asuh demokratis Kedudukan antara anak dan orang tua sejajar. Suatu keputusan diambil

Bersama dengan mempertimbangkan kedua belah pihak. Anak diberi kebebasan yang bertanggung jawab, artinya apa yang dilakukan oleh anak tetap harus di bawah

pengawasan orang tua dan dapat dipertanggungjawabkan secara moral; (4) Pola Asuh Situasional Orang tua yang menerapkan pola asuh ini, tidak berdasarkan pada pola asuh tertentu, tetapi semua tipe tersebut diterapkan secara luwes disesuaikan dengan situasi dan kondisi yang berlangsung saat

itu C. Keluarga

Dalam kehidupan sehari hari , bahwa mengasuh dan mendidik anak adalah tugas dan tanggung jawab Ibu sedangkan Ayah hanya sekedar mencari nafkah. Di berbagai ajaran agama manapun, sejak dulu hingga sekarang, tugas mendidik anak dilakukan berdua, antara Ayah dan Ibu. Ada peran Ayah yang tidak bisa dilakukan Ibu dan begitu juga sebaliknya.

Definisi ayah mengalami variasi diantara budaya-budaya, hal ini disebabkan antar kelompok budaya membentuk definisi mengenai fungsi pengasuhan yang berbeda baik itu bagi ayah maupun ibu (Lamb,dalam Frogman,dkk,2000). Fathering merupakan peran yang dimainkan seseorang yang berkaitan dengan anak, bagian dari sistem keluarga, komunitas, dan budaya (Lynn, dalam

Frogman,dkk,2002). Good fathering merefleksikan keterlibatan positif ayah dalam pengasuhan melalui aspek afektif, kognitif, dan perilaku.

Keluarga adalah suatu ikatan persekutuan hidup atas dasar perkawinan antara orang dewasa yang berlainan jenis yang hidup bersama atau seseorang laki-laki atau seorang perempuan yang sudah sendirian dengan atau tanpa anak- anak, baik anaknya sendiri atau adopsi, dan tinggal dalam sebuah rumah tangga. (Pujosuwarno, 1994 : 11)

Pegertian lain keluarga berada dalam Undang Undang NO 10 Tahun 1992 yang di atur dalam Bab 1, pasal 1,berbunyi "Keluarga adalah unit terkecil dalam masyarakat yang terdiri dari suami-isteri, atau suami-isteri dan anaknya, atau ayah dan anaknya, atau ibu dan anaknya."

\section{HASIL DAN PEMBAHASAN}

\section{Pola Asuh Dalam Keluarga Polisi}

Dengan demikian tidak menutup kemungkinan bahwa banyak orang tua ynag menggunakan pola ini. Dimana dia membedakan pola asuh yang dia gunakan terhadap anaknya yang masih berusia dibawah diaman mereka beranggapan bahwa anak-anak diusia sersebut masih harus mendapatkan perhatian dan kasih sayang yang lebih atau dimanjakan, namun ketika telah berusia cukup remaja maka pola asuh yang digunakannya akan berubah mengikuti usia sang anak atau pola asuh yang dapat berubah dikarenakan jarat antara orang tua dan anak, dimana orang tua 
Hasruddin, Aditya. Pola Asuh Dalam Keluarga Polri di Asrama Polisi...

akan bersikap lembut ketika bersama anaknya namun akan kersikap lebih disiplin ketika anaknya jauh.

Pola asuh campuran tidak hanya berupa pola asuh yang diterapkan berbeda antara pola asuh ibu dan pola asuh ayah, namun berdasarkan penelitian yang dilakukan dalam keluarga polisi dalam Asrama Polisi Toddopuli menunjukan bahwa pola asuh campuran juga dapat terjadi dikarenakan dua faktor yaitu usia dan jarak atara orang tua dan anak. Atau dapat dikatakan bahwa pola asuh yang diterapkan dalam keluarga yang menjadi objek penelitian ini adalah Pola Asuh Situasional.

Seperti yang dijelaskan di BAB sebelumnya bahwa ada sebuah pola asuh yang menggabungkan segala bentuk pola asuh yang dapat diterapkan dalam keluarganya, tergantung dari situasi dan kondisi yang terjadi pada saat itu. Pola Asuh Situasional merupakan pola asuh yang digunakan atau diterapkan dalam keluarga yang menggabungkan segala bentuk pola asuh, baik otoriter, permisif, hinggah demokratis. Pola asuh ini berfokus pada situasi dan kondisi yang sedang terjadi dalam keluarga seperti yang dijelaskan dalam penelitian ini, dengan melihat bagaimana pola asuh berubah dikarenakan jarak anatar anak dan orang tua dan usia anak yang tumbuh dari anak- anak menjadi remaja hinggah dewasa. Dengan demikian ketika kitaingin melihat bagai mana pola asuh yang diterapkan dalam keluarga polisi di Asrama Polisi Toddopuli di kota Makassar dengan melihat dari sudut pandang Fungsional Struktural, kita dapat melihatnya bagai mana penerapan pola asuh situasional dapat diterapkan dalam keluarga ini dan dapat berjalan sebagai mana mestinya.

\section{Alokasi Waktu Dalam Keluarga Polisi Dari beberapa hasil wawancara ini pula}

kita manjadi tau bagaimana cara sekeluarga polisi untuk membagi waktunya, dikarenakan setiap keluarga memiliki cara yang hampir sama namun memiliki sedikit perbedaan. Ada 3 point penting yang dijadikan point utama untuk membagi waktu dalam keluarga ini, yang pertama adalah waktu kerja, kedua adalah waktu bersama anak dan yang ketiga adalah waktu bersama keluar. Dari ketiga point penting diatas keluarga tersebut dituntut untuk dapat membagi waktunya dengan seimbang, dan setiap keluarga memiliki caranya masingmasing namun hasil dari penelitan yang dilakukan kita menemukan bahwa kebanyakan keluarga yang kedua orang tuanya yang berprofesi sebagai sebagai seorang polisi mejadikan waktu diluar dari waktu kerja untuk anak kemudian untuk keluarga. Hal ini dikarenakan sebuah pekerjaan adalah kewajiban meskipun anak dan keluarga adalah sebuah kewajiban namun ada dikarenakan pekerjaan yang merupakan anggota polisi dimana tugas utamanya untuk melayani, melindungi dan mengayomi masyarakat, mereka lebih memprioritaskan tugas dan kewajibannya.

Disamping itu kita juga menemukan fakta menarik bahwasanya dalam keluarga polisi baik ayah maupun ibu yang berprofesi sebagai seorang polisi, tidak menjamin dalam mengasuh anak dan urusan rumah tangga dapat dibagi dengan adil. Dari beberapa orang tua yang dijadikan sebagai sumber informasi menunjukkan bahwa ternyata mereka merasa bahawa peran dalam rumah tangga lebih banyak dibebankan untuk mereka. hal ini dapat kita

lihat bagaimana anak lebih banyak menghabiskan waktu dengan ibu ketimbang ayahnya. Dengan demikian seorang istri dalam rumahtangga keluarga polisi lebih berperan lebih banyak yang artinya meski isrti tersebut merupakan seorang polwan tidak berarti tugas dasarnya sebagai ibu untuk merawar anak seperti menyipkan makan, menyiapkan pakaian dan lain sebagainya tidak diabaikan disamping itu dia juga berperan sebagai istri yang diwajibkan untuk melayani suami dan menyiapkan segala kebutuhannya.

Dengan lebih banyaknya peran seorang ibu dalam mengasuh anak dan keluarga, hal ini berkenaan dengan teori gender. Teori ini berangkat dari gerakan feminist yang menuntu bagai mana kesetaraan ini tidak hanya diberlakukan dalam lingkungan sosial saja seperti pekerjaan dan kedudukan perempuan dilingkungan sosial, namun mereka juga menginginkan bagaimana kesataraan gender ini juga teraplikasikan dalam lingkungan keluarga terlepas dari konsep patriarki yang banyak digunakan di indonesia. Meski demikian, fakta yang kami temukan dalam penelitian yang telah dilakukan menujukkan bawah kesetaraan gender dalam keluarga Polisi yang berada di Asrama Polisi Toddopuli Kota Makassar. Hal tersebut tegambar dari bagaimana pembagian waktu dalam keluarga untuk mengurus pekerjaan dan keluarga, seperti yang telah dijelaskan sebelumnya bahwa ternyata dalam membagi waktu untuk mengurus keluarga masih betumpuh pada seorang ibu. Tidak hanya mengurus pekerjaan, dari beberapa ibu yang 
menjadi narasumber menjelaskan bahwa mereka harus dapat menyeimbangkan urusan antara tugas sebagai seorang ibu, seorang istri dan seorang polwan.

Dengan demikian untuk melihat bagaimana pembagian waktu dalam keluarga dalam keluarga yang berada di Asrama Polisi Toddopuli dengan melihat dari Teori gender kita akan menemukan sebuah ketidak seimbangan gender dalam keluarga ini, meski baik ayah ataupun ibu sama-sama memiliki peran dan kewajiban namun untuk mengurus anak dan keperluan rumah tangga seperti mengasuh, memasak, dan melayani suami tentu seorang ibu akan memiliki peran yang lebih besar.

\section{Dampak Pola Asuh}

Berasarkan wawancara dan penelitian yang dilakukan, kita menukan beberapa dampak dari pola asuh yang diterapkan dalam keluarga polisi dalam Asrama Polisi Toddopuli di kota Makassar. seperti yang kita ketahui dalam pembahasan sebelumnya bahwa ternyata keluarga polisi yang bertempat tinggal dalam Asrama Polisi Toddopuli ini adalah pola asuh campuran atau Situasinonal, dengan demikian dampak yang ditimbulkan dari pola asuh ini pula ada bebagai macam. Tergantung bagaimana dan kapan penerapan pola asuh situasional itu diterapkan. Seperti yang terjadi pada beberapa anak dalam keluarga polisi yang berada di dalam Asrama Polisi Toddopuli.

Sulitnya berinteraksi terhadap lingkungan sosial dengan penerapan pola asuh ini juga memiliki dampak lain. Mulai dari bagaimana orang tua yang dapat megontrol anaknya dalam bergaul yang menyebabkan selama proses tumbuh kembangnya dapat dipantau tanpa adanya rasa cemas dari pengaruh buruk lingkungan sosialnya. Hal ini sejalan dengan pengungkapan dari ibu Nurul. Beliau mengungkapkan Kita dapat melihat fenomena ini dengan menggunakan Teori Fungsional Struktural.

Teori ini berpandangan bahwa sebuah sistem dalam masyarakat akan membuahkan hasil jika semua struktur yang berada di dalamnya bekerja dan berjalan sebagai mana mestinya. Dengan demikian kita juga dapat melihat adanya keterkaitan antara rumusan masalah ini dengan teori fungsional struktural, dimana sebuah rumah tanga akan mengailkan anak yang baik dan berkualitas jika seluruh lingkungan yang ada di sekitarnya befungsi dengan baik. Dalam hal ini, bagaimana peran seorang ayah dan ibu dalam menerapkan pola asuh dalam keluarganya.

Dari penelitian yang telah dilakukan jika kita mengkaji dengan menggunakan teori Fungsional Struktural, kita menemukan bagaimana dampak dari pengaplikasian pola asuh Situasional atau Pola Asuh Campuran terhadap anak. Hasil dari penelitian yang dilakukan ini kami membagi dampak tersebut menjadi dua bagian, yaitu dampak terhadap anak dalam lingkungan keluarganya sendiri dan dampak terhadap anak dalam lingkungan sosialnya. Dari penerapan pola asuh situasional tersebut kita menemukan bahwa ada anak yang ternyata tidak memiliki kedekatan yang begitu kental dengan ayahnya, hal ini dikarenakna pola asuh yang berbeda anatra ayah dan ibunya hal ini membuktikan bahwa adanya disfungsi dari peran orang tua dalam merawat anak sehinggah tujuan utama dari sebuah keluarga tidak berjalan sebagai mana mestinya.

Sedangkan pola asuh ini juga berdampak terhadap lingkungan sosial anak seperti yang dialami oleh seorang anak yang mengungkapkan bagai mana dia sulit untuk berbaur dengan teman sebayalnya, bagai mana dia sulit untuk mendapatkan teman bermain dan lain sebagainya, namun disamping itu dampak positive yang diperoleh dari penerapan pola asuh tersebut dalam kehidupan sosialnya, sang anak menjadi memiliki waktu yang lebih banyak untuk dihabiskan bersama keluarganya dan orang tuanya pun mampu memantau secara langsung bagai mana tumbuh kembang sang anak tampe harus khawatir dengan pengaruh buruk dari pergaulan anaknya.

\section{SIMPULAN DAN SARAN}

Berdasarkan hasil penelitian dan pembahsan, maka secara garis besar kita dapat menyimpilkan beberapa point penting dan disimpulkan sebagai berikut: (1) Sebuah pola asuh atau dapat dikatakan dengan cara atau metode yang digunakan untuk mengasuh anak merupakan sebuha langkah yang dilakukan oleh kedua orang tua dalam merawat, mengajar serta memelihara anaknya hingah menjadi dewasa dan diangap mandiri. Dalam proses penerapan loa asuh, orang tua adalah ujung tombak dari pengaplikasian pola tersebut dan dalam penelitian ini orang tua yang menjadi objek penelitian adalah keluarga yang bertempat tinggal di dalam Asrama Polisi Toddopuli di Kota Makassar dengan kriteria kedua orang 
Hasruddin, Aditya. Pola Asuh Dalam Keluarga Polri di Asrama Polisi...

tuanya berprofesi sebagai polisi. Dari penelitian yang dilakukan kita menemukan bahwa dari beberapa bentuk pola asuh yang ada dan sering dipakai dalam keluarga ternyata mereka menggunakna pola asuh campuran dan pola asuh situasional untuk diaplikasikan dalam rumah tanga mereka dan menjadi standar untuk membesarkan anaknya. Mereka manggunakan pola asuh ini dipengaruhi oleh beberapa hal, mualai dari jarak anatar orang tua dan anak yang diakibatkan oleh tugas salah satu orang tuanya yang berada di luar daerah, waktu antara tugas kantor dan keluarga, dan lain sebagainya. Dengan semilikan pola asuh yang paling ideal untuk diaplikasikan dalam keluarga polisi yang tinggal di dalam Asrama Polisi Toddopuli adalah pola asuh campuran dan pola asuh situasional; (2) Dalam sebuah keluarga polisi yang berada di Asrama Polisi Toddopuli Kota Makassar cenderung memakai konsep patriarki, pada penerapannya bahwa patriarki lebih menempatkan laki-laki sebagai pemimpin kekuasaan. akan tetapi, seorang ibu dalam keluarga cenderung memiliki peran yang sangat besar di banding seorang ayah. dalam penerapan yang terjadi, bahwa seorang ibu dalam keluarga cenderung memiliki peran yang lebih besar daripada ayah. hal ini dikarenakan karena peran seperti mengasuh anak, membereskan rumah termasuk dapur lebih banyak pada ibu. Pola ini berbanding terbalik dengan konsep gender bahwa peran perempuan dan laki-laki di tentukan secara sosial dan bukan dari pemberian tuhan atau kodrat manusia. konsep gender merupakan sebuah konstruksi sosial yang tidak tetap dan dapat berubah- ubah sewaktu-waktu menurut waktu dan budaya. Sehingga penerapan konsep gender dalam keluarga juga dapat berubah seiring dengan pola pikir masingmasing yang dipengaruhi oleh budaya ataupun agama. terlepas daripada itu, bahwa konsep yang dipakai dan menjadi sebuah dasar dalam keluarga khususnya dalam keluarga hingga saat ini masih memakai konsep patriarki. Meskipun demikian, bahwa seperti yang dijelaskan sebelumnya ternyata permbagian peran yang dibebanan kepada ayah tidak banyak dan cenderung tidak seimbang dengan peran yang diberikan oleh seorang ibu yang harus menyeimbangkan antara tugas sebagai seorang ibu, tugas sebagai seorang istri, dan tugasnya sebagai seorang polwan. (3) Dalam sebuah penerapan pola asuh dalam keluarga pasti akan memilki sebuah dampak, baik itu dampak positive maupun dampka negative, Semua tergantung apa dan bagaimana sebuah pola asuh tersebut diaplikasikan dalam keluarga. Dalam penelitian yang telah dilakkan dalam keluarga polisi di dalam Asrama Polisi Toddopuli di Kota Makassar, dalam pembahasan sebelumnya bahwa ternyata pola asuh campuran dan pola asuh situasional merupakan pola asuh yang sering digunakan dalam keluarga tersebut. Penerapan pola asuh tersebut memiliki dampak terhadap anak dan dampak tersebut kita bagi menjadi dua, yaitu dampak terhadap kepribagian anak dalam keluarga dan dalam lingkungan sosial atau pergaulannya. Keduanya memiliki dampak negative dam positive. Dalam penelitian yang dilakukan kita menemukan bahwa dampak terhadap kepribadian anak dalam keluarganya memiliki dampak negative seperti, anak tersebut akan cenderung memiliki kedekatan yang lebih erat terhadap salah satu keluarganya, hal ini dikarernakan pola asuh ayng berbeda nataara bapak ataupun ibu, sedengkan dampak positive daripenerapan pola asuh ini dalam keluarga menunjukkan bahwa dnegan penerapan pola tersebut, anak tersebut diharapkan akan memiliki kepribadian yang lebih baik. Sedangkan dampak pola asuh terhadap anak dalam lingkungan sosialnya memiliki pengaruh terhadap cara bergaul dengan teman sebayanya. Adapun dampak negative yang ditimbulkan dari penerapan pola asuh tersebut, sang anak akan cenderung sulit bergaul dengan teman sebayanya dikarenakan sang anaka akan merasa dipenjara sehinggah untuk mecari teman sepergaulannya anak tersebut akan merasa kurang baik dalam bekomunikasi atau bergaul. Sedagkan dampak positive dari penerapan pola asuh tersebut, sang anak anak memiliki waktu lebih banyak dengan keluarga, mengabihskan waktu dengan orang tua serta orang tua juga mempu memantau perkembangan anak tanpa khawatir adanya dampak buruk dari pergaulana anaknya.

Sehubungan dengan kesimpulan di atas, maka penulis ingin mengemukakan saran-saran sebagai berikut : (1) Para orang tua yang berprofesi sebagai seorang polisi ataupun polwan di dalam Asrama Polisi Toddopuli, mampu menerapkan pola asuh yang tepat dalam membesarkan anaknya sehinggah anak tersebut tidak hanya mampu menjadi pribadi yang baik namun dapat menjadi pribadi yang tegas serta dapat menjadi anak yang taat kepada tuhan dan negaranya. Serta berhati- hati dalam mengsuh anak, dikarenakan anak sangat rentan terhadap lingkungan dan keluarga di usia-usia tertentu; 
(2) Diharapkan kepada para orag tua yang memiliki kewajiban tidak hanya di dalam profesinya sebagai seorang polisi dan polwan, namun tetap sadar bahwa kewajiban dalam mengajar, merawat serta mengasuh anak juga merupakan sebuah kewajiban yang besar sebagai seorang orang tua dalam keluarag. Jadi peneliti berharappara urang tua mampu mengatur, meluangkan waktu antara profesi, keluarga serta waktu bersama anak. (3) Terlepas dari dampak positife yang tentu perlu di jaga agar dampak tersebut dapat bertahan, sedangkan diharapkan dampak negative baik dari pola asuh yang kurang tepat atau pola asuh yang bereko dalam tumbuh kembang anak dapat berkurang, sehinggah segala sesuatunya dapat berjalan dengan baik dalam keluarga maupun lingkungan sosialnya.

\section{DAFTAR RUJUKAN}

Aan Komariah dan Djam'an Satori. 2012. Metodologi Penelitian Kualitatif. Ahmad, Abu \& Uhbiyatu, Nur. 2001. Ilmu Pendidikan. Rineka Cipta: Jakarta.

Ahmadi dan Widodo Supriono. 2008. Psikologi Belajar. Jakarta: Rineka Cipta.

Ahmadi, Abu. 1991. Sosiologi Pendidikan. Jakarta : PT Rieneka Cipta. Bandung: Alfabeta.

Danny I. Yatim Irwanto. 1991. Kepribadian Keluarga Narkotika. Jakarta : Arcan

Dariyo, A. 2004. Psikologi Perkembangan Remaja. Bogor: Ghalia Indonesia

Gunarsa, Singgih D. 2004. Psikologi Perkembangan Anak Dan Remaja. Jakarta : Gunung Mulia.

Hurlock, E.B. 1999. Psikologi Perkembangan: Suatu Pendekatan Sepanjang Rentang Kehidupan. Alih bahasa: Istiwidayati \& Soedjarwo. Edisi Kelima. Jakarta: Erlangga.

Hurlock, Elizabeth B. 1990. Perkembangan Anak, Terj Meitasari Tjandrasa, Jakarta : Erlangga.

Jurdi, Syarifuddin. 2015.Kekuatan-Kekuatan Politik Indonesia: Kontestasi Ideologi Dan Kepentingan.Cet I;Gowa: Laboratorium Ilmu Politik.

Koentjaraningrat. 1997. Metode Penelitian
Masyarakat. Gramedia : Jakarta Kualitatif Dan R\&D. Bandung: Alfabeta

Mangoenprasodjo, A.S. 2004. Pengasuhan Anak di Era Internet. Yogyakarta : Thinkfresh.

Mansour Fakih. 1999. Analisis Gender dan Transformasi Sosial, Yogyakarta: Pustaka Pelajar

Mufidah, Ch. 2013. Psikologi Keluarga Islam Berwawasan Gender Edisi Revisi. Malang: UIN-Maliki Press.

Moleong, Lexy. 2002. Metodologi Penelitian Kualitatif. Bandung: PT.remaja

Nasaruddin Umar,2001. Argumen Kesetaraan Jender "Perspektif al-Quran", (Jakarta: Paramadina, h. xxviii)

Nugroho, Riant. 2008. Gender dan Administrasi Publik. ; Yokyakarta: Pustaka Pelajar

Poerwandari, E. K. 2005. Pendekatan kualitatif untuk penelitian perilaku Publik dan Ilmu Sosial lainnya.Jakarta: Putra Grafika

Pujosuwarmo, Sayekti. 1994. Bimbingan Konseling dan Keluarga. Yogyakarta :Menara Mass Offset

Puspitawati, Harrien. 2012. Gender dan Keluarga : Konsep dan Realita di Indonesia. Bogor : PT IPB Press.

Puspitawati. 2013. Konsep, Teori, dan Analisis Gender. Bogor: PT IPB Press. Pustaka Pelajar.

Raho, Bernard ,SVD . 2007.Teori Sosiologi Modern. Jakarta: Prestasi Pustaka. Rosdakarya.

Sugiyono. 2014. Metode Penelitian Pendidikan

Pendekatan Kuantitatif. Jakarta: Erlangga.

Soekanto, Soerjono. 2004. Sosiologi Keluarga. Jakarta: Rineka Cipta

Thoha dkk. 2004. Metodologi Pengajaran Agama. Yogyakarta: Pustaka Pelajar.

Zam, Andi. 2013. "Budaya Kerja Kepolisian Dalam Sistem Pelayanan Masyarakat Di Polres Bone". Fakultas Ilmu Sosial. Universits Hasanuddin. Makassar. 